\title{
Food and Agriculture Organization of the United Nations (FAO)
}

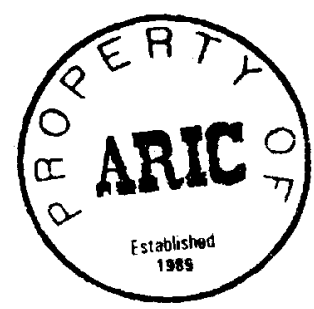

\section{DROUGHT ASSESSMENT IN SOUTHERN AFGHANISTAN \\ (KANDAHAR, HELMAND AND NIMROZ)}

\author{
Prepared by: \\ Dr. M. Hassan Kamran \\ Sultan M. Ahmady \\ Agency Coordinating Body for Afghan Relief \\ Survey Unit
}

Peshawar 
ACKNOWLEDGEMENTS i

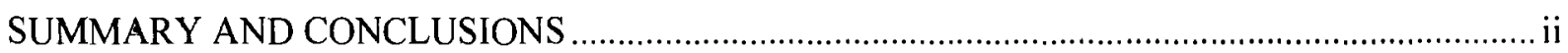

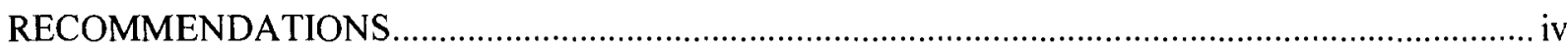

1. INTRODUCTION

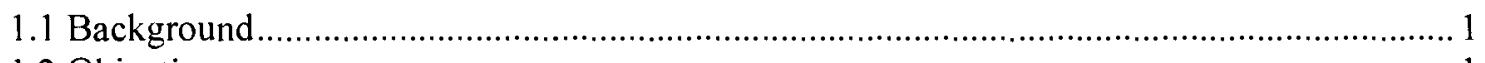

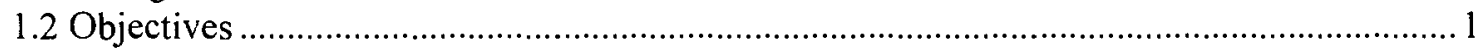

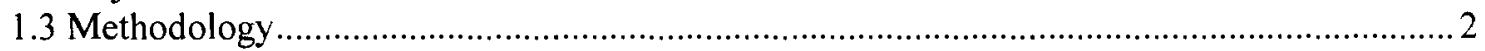

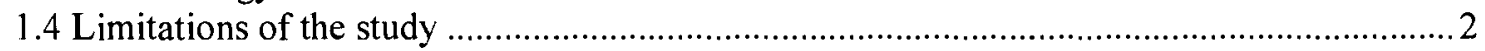

2. GENERAL INFORMATION, RESULTS OF CONSULTATIONS, INTERVIEWS AND OBSERVATIONS

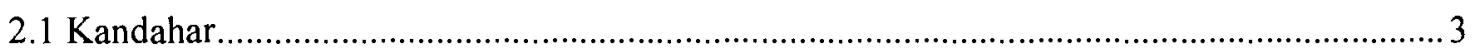

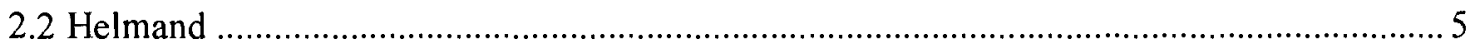

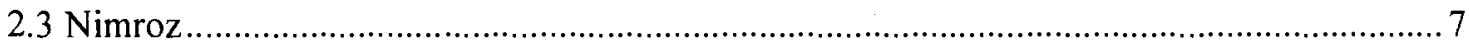

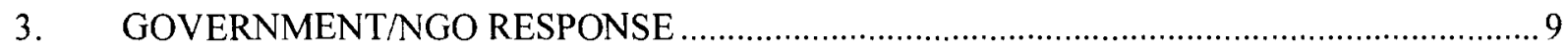

4. APPENDIX Questionnaire used during consultation

\section{LIST OF TABLES}

Table 1: Districts of Kandahar and their estimated population ............................................ 3

Table 2: Districts of Helmand and their estimated population ........................................... 5

Table 3: Districts of Nimroz and their estimated population ............................................ 7

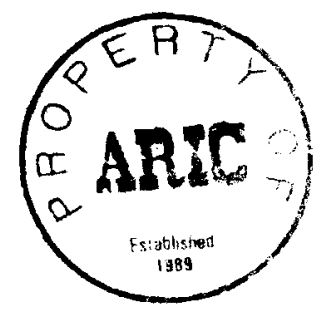




\title{
ABBREVIATIONS, WEIGHT AND MEASUREMENTS
}

ACBAR

ADA

FAO

MCI

NGO

UNOPS

VARA

WFP
Agency Coordinating Body for Afghan Relief

Afghan Development Association

Food and Agricultural Organization of United nations

Mercy Crops International

Non governmental Organization

United Nations Office Project Service

Voluntary Association for the Rehabilitation of Afghanistan

World Food Program of United nations

\author{
1 Seer $=7 \mathrm{~kg}$ \\ $1 \mathrm{Mann}=4.5 \mathrm{~kg}$ \\ $1 \mathrm{Jirib}=0.2 \mathrm{ha}$ \\ 1 Pak. Rupee $=$ Afs. 1130 \\ $1 \$$ U.S $=$ Afs. 65000 \\ $1 \$$ U.S $=$ Rs. 54.20
}




\section{ACKNOWLEDGEMENTS}

We would like to extend our deep appreciation to FAO (Crops and Livestock), VARA, WFP, ADA, UNOPS, MCI, Local authorities, drought affected farmers, and nomads for their cooperation who were consulted and interviewed by us during the assessment of drought in southern Afghanistan (Kandahar, Helmand and Nimroz.)

Special thanks are also due to Mr. M. Omar Anwarzay, Manager of ACBAR Survey Unit for his encouragement and support related to general supervision and administrative aspect of this project. Thanks go also to Mr. Thomas Muller, ACBAR Coordinator for reading and editing this report.

We are also grateful to the computer and report writing sections of ACBAR Survey Unit who typed and edited this report to be submitted to FAO Afghanistan.

\section{Dr. M. Hassan Kamran (Consultant)}

Sultan Mohd Ahmady (Field coordinator) 


\section{SUMMARY AND CONCLUSIONS}

Southern Afghanistan which covers Kandahar, Helmand and Nimroz provinces has an estimated population of more than 2 million. The total land area of this region is 151,369 square kilometers and population density per square kilo meter is 13.2 persons.

- The southern region, which used to be called the bread basket of Afghanistan, has been extremely badly struck by the drought in 2000 . The drought has affected livestock (nomads and local owners), field crops (rain-fed and irrigated wheat) and orchards to various degrees.

\section{- Nomads}

Nomads in all of the above 3 provinces are hit hardest by the drought. It is estimated that $95-100 \%$ of nomads are affected by the drought. Many of their livestock have died of starvation due to lack of water and grazing land. The mortality rate of their livestock is estimated to be more than $50 \%$.

\section{- Rain-Fed Wheat}

The second category affected the most by the drought in all 3 provinces are rainfed wheat farmers. According to our personal observations of some wheat fields and the information obtained during the interviews and consultations, rain-fed wheat like livestock are severely affected by the drought (90-95\%).

\section{- Irrigated Wheat}

The third group of the drought affectees are the irrigated wheat farmers. These wheat farmers are using the water from canals and rivers for irrigation, however, the water level in the 3 important rivers of the region, (Arghandab, Helmand and Khashrud) has reduced by almost $2 / 3$, and in some parts there was very little water or it was completely dry.

The shortage of water for irrigation has affected the irrigated wheat according to some estimations by $40-50 \%$. The exact amount of harm done to the wheat by shortage of water can not be determined until the wheat is harvested and the yields are compared with previous years production.

The wheat fields which use water from Karezes for irrigation are also affected by the drought. The water level in Karezes is low. The Karezes are old and in some parts collapsing and blocked with dirt. The Karezes need cleaning and repairing. According to our interviews with the owners of Karezes, the water level in Karezes due to this year drought has reduced by almost $30 \%$. Consequently, the frequency of irrigation for the wheat fields is less while a smaller amount of land is cultivated compared to previous years due to the shortage of water in Karezes. 


\section{- Orchards}

The last category affected by the drought are orchards. Shortage of water has affected the orchards through a reduction in frequency of irrigating time and thus their growth is hampered and in some cases diseases are attacking the orchards. If it doesn't rain and the supply of water is reduced further, the production of horticultural crops will be tremendously affected and therefore will inflict a great economic loss on the farmers of this region.

\section{- Kandahar}

The province of Kandahar which has 15 districts and a total population of close to 800,000 is severely affected by the drought. 11 out of 15 districts are hit by the

- drought, which cover 296,853 persons (37\%).

As mentioned before nomads (kochis) are severely affected by the drought, in Kandahar province according to some estimates 33,000 nomads need food, water and feed for their remaining animals. 2000-6000 families of nomads whose livestock were facing starvation due to the lack of water and feed were evacuated from Registan area by local authorities and were transported to Ghazni, Badghis and Herat Provinces.

\section{- Helmand}

Helmand province, the largest in the country, which has a total population of close to 1.1 million and a total area of 62,337 square kilometers is also affected by the drought. Out of the total 15 districts, 7 of them are severely affected, which covers 499,513 persons ( $46 \%$ of the total Helmand population).

A lot of nomads are living in Helmand province. Nomads and their livestock just like in Kandahar are severely affected by the drought. Approximately 100,000 nomads are living in Helmand, $80 \%(80,000)$ are very badly affected by the drought. The nomads need food, water and feed for their animals.

\section{- Nimroz}

Nimroz is one of the most under developed provinces in Afghanistan. It is also severely hit by drought. This province has a total area of 41,356 square kilometers and a population of 136,300 persons. The people of Nimroz have very limited educational and health facilities, poor infrastructure and very bad socio-economic conditions. Among all the misery, people have been drinking salty water for years. The drought has further exacerbated the problems that people already face. All five districts of Nimroz are affected by drought. According to VARA, an active NGO, $80 \%$ of total population of Nimroz or 109,040 people are affected by the drought. Nomadsin Nimroz, just like in Kandahar and Helmand are also severely affected by the drought. 
According to the information obtained during the visit to Nimroz, there are 20,000 nomads who have been severely affected by the drought. They need food, water and feed for their animals.

In conclusion 905,406 persons (44.5\%) out of the total population of $2,028,571$ are affected by the drought in the southern Afghanistan.

- Nomads in the southern region who are hit hard by the drought are approximately 133,000 persons. These people require immediate assistance such as food for the themselves, feed for livestock and water for both.

\section{$\therefore$ RECOMMENDATIONS}

Recommendations originating from our assessment of drought situation in southern region of Afghanistan can be divided in 2 parts.

\section{Relief Operation /Emergency Assistance}

As mentioned in this report previously drought affectees in southern region are different.

\section{A. Nomads (Kochis)}

1. Food distribution: For estimated 133,000 drought affected nomads, we propose emergency food distribution of 26,334 MT of wheat for one year which is worth approximately 6.58 million U.S dollars. This calculation is based on WFP estimation of daily calories and wheat requirements.

The ordinary life of affected nomads is very disturbed. During this one year period they will restart their livelihood and organize their drought affected living for the future.

2. Building of Camps for affected nomads: In order to help nomads to stay together and to prevent their migration to other areas which will cause overgrazing of virgin pastures and would create other social tensions and conflicts. We propose a camp to be built close to the sources of water. One tent which costs about 50 US dollars is thought to be enough for a family of 5 persons, thus totally 26,600 tents are required for all the affected nomads which will cost around $1,330,000$ U.S dollars.

\section{B. Feed for all the remaining livestock}

According to FAO/Livestock, 4 million sheep and goats were living in southern Afghanistan in 1997/1998. It was estimated that more than $50 \%$ of livestock have died due to lack of feed, grazing areas, pastures and water. If a concentrated feed made of cotton seed cake, barley and corn which are locally produced and 
recommended by livestock experts is prepared, this could be given to the 2 million remaining sheep and goats for one year. Their estimated feed is calculated to be 360,000 MT which will cost 75.87 million U.S dollars. This feed could be provided to the livestock owners for 6 months or one year depending upon the source of funding. Molasses/urea bricks as feed is another alternative. The cost of both should be compared and the less expensive should be given to the livestock.

\section{Food for total affected population of southern region other than nomads}

Total affected population in Kandahar, Helmand and Nimroz provinces is estimated to be 903,406 . We propose that wheat be distributed to this population for 6 months which will amount to 89437.2 MT which is equivalent to 22.36

- million U.S dollars. For the other 6 months cash for work programmes should be initiated for short term projects which will assist both the people affected by the drought and the community. The amount of cash to be given will be determined by the financing source considering the cost of living in each province.

\section{Provision of potable water}

The city of Kandahar is severely confronted with shortage of drinking water. As a relief operation, water can be provided by water tanks which could use the water from Arghandab and other rivers in Kandahar and be distributed to the residents of Kandahar city at a moderate price to those who can afford and free of charge to the vulnerable population.

\section{E. Health related emergency Assistance}

Shortage of food causes malnutrition in human beings and animals which leads to different types of diseases. According to information obtained, drought affected population and livestock will be facing health problems, therefore mobile health and veterinary clinics are required in the areas where they are mostly needed.

\section{Short and Medium Term Interventions}

In addition to relief operation of providing potable water for Kandahar city, it is recommended that after deepening and drilling of wells in areas where water table is high enough to be used, hand pumps should be installed in every village based on the number of households living in the common areas. Hand pumps could be financed by donors or can be given to a group of people who share one hand pump on along term credit basis.

To save the orchards from further destruction of drought, it is recommended that 4-6 inches water pumps which could irrigate $25-30$ jeribs (5-6 ha) of agricultural land and will cost around 500 U.S dollars should be provided to the farmers who 
need them on credit basis or if financed by donors, they can be distributed to the needy and economically weak orchard growers free of charge.

In order to save water from further reduction, small dams should be built so that the water can be stored there for future consumption. Cash for work as proposed in relief operation can be used to clean and repair the fallen and blocked Karezes, streams and canals by the resident of each area. Water use practices should be improved and the misuse of water should be reduced. Improved irrigation - techniques should also be practiced and water distribution should be planned in a way so that maximum utilization of water resources takes place and wastage of the water is prevented. People should also be informed and made aware of water conservation practices.

$\therefore$ As it was mentioned in this report, Nimroz province especially Zaranj, the capital city, is faced with a severe lack of potable water. People have been drinking salty water for years. We propose, to those who are interested in humanitarian work to finance this project, the processing of salty water in this very under developed province so that the residents of this city may have potable water which is the basic right of every human being.

To keep the remaining drought affected livestock alive and avert drought related problems, the following measures should be taken into consideration.

- Veterinary services to be provided to combat drought related and other diseases;

- Making available vaccine and medicine;

- Increasing fodder production through introduction of fodder crops and pasture management services;

- Supporting the extension of animal husbandry in the areas most needed; and

- Restocking.

Other short and medium term interventions in addition to irrigation include the following:

- Provision of improved varieties of seed;

- Selective mechanization;

- Plant protection;

- Chemical fertilizers;

- Vocational training;

- Research; and

- Extension 


\section{INTRODUCTION}

\subsection{Background}

Afghanistan a war-torn country which has still not recovered completely from 22 years of political unrest, social and economic hardship has been confronted with natural disasters (flood, hail, drought, earthquake) from time to time.

Drought has hit many parts of the country during different time periods. In 19701971 the central, northern and northeastern regions were hit by severe drought causing displacement of people, loss of animals and a major food shortage. Other droughts occurred in 1948 and 1955 in southern Afghanistan; 1961-1962 in central Afghanistan; 1973 in central and northern regions; and in 1977 in north-western areas.

The current drought of 2000 is the worst to strike Afghanistan since 1971. The most severely affected areas of Afghanistan are Kandahar, Helmand, Nimroz, Farah and Zabul provinces located in the south. According to FAO/WFP crop Assessment report, this region produced 33,000 MT of rain-fed wheat and 494,000 MT of irrigated wheat in 1999 making this region the most productive in Afghanistan.

The drought has worsened the already difficult socio-economic conditions prevailing in the country particularly in southern Afghanistan. The drought has affected livestock and cereal crop production detrimentally in the region which plays an important role in agricultural economy of Afghanistan. Southern Afghanistan had insufficient rainfall in 1998/1999 and it has been followed by months of unusually dry weather with far below average precipitation levels. The situation is expected to worsen as the next rains are not due until December 2000 or January of 2001.

There are new reports that moderate drought is affecting much of the rest of the country. Thus there is a fear of general food shortage in the future which will further exacerbate the hard economic conditions that the Afghan nation has faced for almost a quarter of a century.

\subsection{Objectives}

The objectives of the study were to assess the extent of drought in Southern Afghanistan especially in Kandahar, Helmand and Nimroz provinces through the following steps:

- To review through consultations with local authorities, affected nomads and farmers, UN agencies and NGOs active in the affected areas, all available information on the impact of the drought on the agriculture, livestock and related sectors; 
- To analyze available information on assistance provided or planned to be granted to the agriculture sector to the affected farming communities by the Government and/or by the international donor community, including NGOs;

- To assess the current extent of the drought and related damage on the agricultural sector, including estimation of lost production, quantification of the affected population in need of assistance (including geographical distribution) and quantification of inputs required; and

- $\quad$ To identify technical specifications of inputs needed.

\subsection{Methodology}

A local consultant and the Agency Coordinating body for Afghan Relief (ACBAR) Survey Unit Field Coordinator visited the drought affected area of southern Afghanistan in Kandahar, Helmand and Nimroz provinces in order to see and examine closely the affects of drought on agricultural production, livestock and other related areas. They contacted and consulted local Taliban Authorities, a sample of affected farmers and nomads, NGOs and UN agencies working in the region and collected information about the drought.

In addition printed material about the drought from UN and other organizations, literature pertaining to southern Afghanistan and drought as a whole were studied. The research enabled greater understanding of the problems caused by drought and assisted in identifying mechanisms for coping with the problems of drought facing the people of southern Afghanistan.

\subsection{Limitations of the study}

The scope and objectives of this drought assessment project in southern Afghanistan which included Kandahar, Helmand and Nimroz provinces were very widely formulated.

The time framework of one month period allocated for this mission in which consultations and interviews with some affected nomads and farmers, local authorities, NGOs and UN agencies working in the area and writing of the report were included, was not long enough for all the related issues to be fully covered and deeply analyzed. In addition to the constraint of one month time period, lack of reliable statistics and the inconsistency of the collected data and information from different sources contacted, were other limitations. Lack of cooperation from some agencies active in the area was also discouraging.

In spite of the above mentioned problems, we have tried hard to gather and make sense out of the collected information related to drought, which will hopefully be useful to FAO, other UN agencies and local authorities. 


\section{GENERAL INFORMATION, RESULTS OF CONSULTATION, INTERVIEWS AND OBSERVATIONS}

Information about Geography, Population, Agriculture, Livestock and the affects of drought on various sectors, general economic conditions and the problems of people in the 3 target provinces (Kandahar, Helmand, Nimroz) for this study is provided.

\subsection{Kandahar}

The province of Kandahar located in southern Afghanistan has an estimated population of 799,537 and 15 districts. Kandahar's total area is 47,676 square kilometers. The altitude of Kandahar ranges from a low of $900 \mathrm{~m}$ in the desert of

$\therefore$ Reg to a high of $1750 \mathrm{~m}$ in the mountains of Maruf district. Kandahar is bordered by Pakistan to the south-east, the province of Zabul to the north-east, Uruzgan to the north and Helmand province to the west. The 15 districts of Kandahar and their estimated population are depicted in Table 1.

Table 1: Districts of Kandahar and their estimated population

\begin{tabular}{ll}
\hline Districts & Population \\
\hline Arghandab & 56500 \\
Arghestan & 26100 \\
Kandahar city (Dand) & 403800 \\
Dahla (Shawali Koot) & 32800 \\
Daman & 22300 \\
Ghorak & 7200 \\
Khakraiz & 17300 \\
Maruf & 25000 \\
Maywand & 50600 \\
Panjwai & 95300 \\
Reg & 1400 \\
Shegah & 6053 \\
Shorabak & 8700 \\
Spin boldak & 36900 \\
Nish & 9584 \\
\hline Total & 799537 \\
\hline Source: Estimated population of Afghanistan (1996-1997), Central Statistics office, Islamic state of Afghanistan.
\end{tabular}

Kandahar is best known for many varieties of fruits such as grapes, pomegranates and apricots. The important field crops are wheat, barley and maize. Apples, figs, peaches, pears, almond and plums are also grown in Kandahar. Industrial crops such as cotton, sesame and nuts are also planted in Kandahar province.

According to the consultations in Kandahar province, with different organizations, the districts that are most affected by the drought are Spin Boldak, Shorabak, Maruf, Shegah, Arghestan, Maywand, Ghorak, Khakraiz, Reg, Daman and Panjwai. These districts have a population of 296,853 or $37 \%$ of the total population of Kandahar.

The affects of the drought in Kandahar can be divided in to 5 categories in degree of their intensity: 
1: $\quad$ Livestock of nomads

2: $\quad$ Rain-fed wheat

3: Wheat irrigated by rivers and canals

4: $\quad$ Wheat irrigated by Karezes

5: $\quad$ Orchards

Nomads were mainly scattered in the districts of Reg, Shegah, Maruf and - Arghistan. These areas used to be very suitable for grazing of livestock. Currently these grazing land areas are dry and without vegetation due to the lack of rain.

2000-6000 families of nomads whose livestock were facing starvation were evacuated from the Registan area by the Taliban Authorities and were transported to Badghis, Herat and Ghazni provinces so that their livestock could survive. A further 800 families were brought to Kandahar city. Currently 4200 families of nomads or 42,000 people are in Maywand, Shigah, Dand and Shorabak districts (The population figure is calculated on the basis of 10 persons per family). Of these, 33,000 are severely affected and need food, feed and water. The mortality rate among livestock is estimated to be $50-55 \%$. Local livestock owners are also affected by the drought. Their loss is estimated to be $25-30 \%$.

The second category affected by the drought after the nomads are cereal crops especially rain-fed wheat. Through observation in Spin Boldak district it is estimated that $95-100 \%$ of the wheat crops has been lost due to the drought.

The third category affected by the drought are the irrigated wheat areas. The irrigated wheat which use water from canals and rivers are estimated to be affected by more than $60 \%$ due to the shortage of water in rivers. The irrigated wheat which use the water from Karezes are also affected. Their loss was estimated to be by $40-45 \%$. The water level in the Karezes is not as severely affected as the rivers. The wheat growers are also faced with problem of birds attacking their wheat crop.

Daman district which produces $50 \%$ of the Kandahar irrigated wheat is now facing shortage of water and only $50 \%$ of the total wheat area is cultivated this year. Talking with the farmers of Daman district, they indicated that their irrigated wheat loss due to not having enough river water might reach $75 \%$ this year.

FAO /Crops has an experimental farm of 1200 Jeribs (240 hectars) in Daman district where they have cultivated 32 tons of improved varieties of wheat. According to the personal in charge of the farm, due to the shortage of water, the wheat farm is dry and there is a possibility that the farm will not even produce the amount of 32 tons seed which is cultivated there.

According to interviews with local authorities and NGOs working in Kandahar, there is a shortage of drinking water and water for irrigation in Kandahar city which needs immediate attention from local authorities, NGOs and international organizations. 
The Arghandab river crossing the center of Kandahar province is the tributary of Helmand river. The river used to flood in the spring when there were rains and the snow melted. This year due to the lack of rain and snow, the water level of the river is $60 \%$ below normal, the lowest level for many years.

The last category affected by the drought are orchards. The damage of the drought on orchards according to the agriculturists interviewed in Kandahar could be - estimated at $25-30 \%$, at the time of consultation.

The amount of water in the Dahla dam on the Arghandab river which provides water for Kandahar has reduced by more than 50\%. According to the Afghan Development Association (ADA), people who grow orchards normally irrigate their orchard at 8 day intervals, now due to the shortage of water they irrigate their orchards at intervals of 24 days. This means that the orchard growers who use water from the rivers are also affected by the drought. If the drought continues and the amount of water decreases the orchard growers will be severely affected in the coming months just like the nomads and wheat growers.

\subsection{Helmand}

Helmand province is also located in southern Afghanistan. The total area is 62,337 square kilometers. Helmand borders the provinces of Nimroz in the west, Ghor and Uruzgan in the north, Kandahar in the east and Pakistan in the south. Helmand's altitude ranges between $1000 \mathrm{~m}$ to $1800 \mathrm{~m}$, except in the mountain area where it reaches around $2300 \mathrm{~m}$. The major river in the province is the Helmand river. Helmand is composed of 15 districts. Helmands population is estimated to be $1,092,734$. The total districts of Helmand province and their related population are shown in table 2.

Table 2: Districts of Helmand and their estimated population

\begin{tabular}{ll}
\hline Districts & Population \\
\hline Baghran & 83025 \\
Marja & 115913 \\
Bust & 59285 \\
Sarban Qala & 62491 \\
Deshu & 19099 \\
Garmser & 64721 \\
Kajaki & 92627 \\
Khanni shin & 9325 \\
Mosa Qala & 172998 \\
Nadi Ali & 60360 \\
Nahr-e-Saraj & 106096 \\
Nawa-e-Barakzai & 52860 \\
Washir & 28695 \\
NawZad & 121650 \\
Baghni & 43589 \\
\hline Tatal & 1092734 \\
\hline
\end{tabular}

Source: Baseline survey of Helmand province, Agency Coordinating Body for Afghan Relief (ACBAR), May 2000 
Out of the above 15 districts, 7 of them Baghran, Deshu, Garmser (Hazarjuft), Khannishin, Musa Qala, Washir, and NawZad, with a population of 499,513 (46\%) are most affected by the drought. Local livestock owners are also affected by the drought, according to some estimates by $25 \%$.

Helmand province like Kandahar is an agricultural province with a modern irrigation network constructed between late 1950's and early 1970's. The climate of Helmand is suitable for a variety of field and horticultural crops. Helmand is characterized by low rain fall, cool winters and hot summers. The field crops are wheat, maize, barley, rice and mung beans. The fruits grown in Helmand are pomegranates, apricots, peaches, plums, mulberries, almonds and watermelons. The best quality of cotton is produced in Helmand. Vegetables such as onions, potatoes, egg plants, carrots, okra, spinach and pepper are also grown in this province. Opium poppy which requires a lot of water before it gets ready for harvest, is also affected by the shortage of water. It is estimated that the production of opium poppy will be reduced by $40-50 \%$. The drought has affected livestock, field crops and orchards. In Helmand, nomads also own livestock, mostly sheep and goats. The majority of local farmers own cows.

According to the Planning Department in Lashkerga, the capital city of Helmand, there has been no rain for a year in Helmand. The nomads are severely affected by the drought. The grazing areas for their animals are dry and empty and there is a shortage of fodder for livestock. According to the available information, $80 \%$ of nomads in Germser, Khannishin, Nadi Ali and Marja are affected by the drought. Some nomads from Hazarjuft have moved to Ghazni and Badghis provinces in search of fodder for their livestock. The Taliban Authorities have helped the nomads by transporting 250,000 livestock to Badghis and 6000 to Ghazni.

There are approximately 100,000 nomads living in Helmand province. $80 \%$ of them (80000) are badly affected by the drought and need food and feed for their animals.

After livestock comes the field crops especially rain-feed wheat which are affected the most by the drought. Wheat fields in Helmand as in Kandahar province are irrigated by rivers and Karezes. The water level of Helmand river, the main source of irrigation water, is down by $2 / 3(66 \%)$ due to the lack of rain. In previous years, however, there was so much water that in the spring time this river was prone to flooding.

Kajaki dam built on the Helmand river in Kajaki area is 300 feet high and 900 feet long in normal years. This dam despite little rains has provided water for agricultural crops in Bust, Garmser, Nadi Ali, Gerishk, Nawa and Sarban Qala. The height of water in this dam according to some estimates is down by six meters.

The districts which use water from Karezes for their irrigation are Washir, Naw Zad, Musa Qala and Kajaki. The districts which use water from rivers are, Sarban 
Qala, Grishk, Nadi Ali, Marja, Nawa-e-Barkzai, Garmser, Khannishen, Dishu and some parts of Kajaki.

The wheat in Helmand province irrigated by Karezes and rivers are not as badly affected by drought as in Kandahar. The birds attack the wheat in Helmand and created a big problem for Helmand farmers. The drought related damage of wheat could be estimated at close to $35-40 \%$ during the time in which interviews were conducted.

Orchard crops are also affected by drought but not as much as livestock and field crops. If the drought and the shortage of water continues, the orchards crops will also be damaged intensively and different diseases and insects will further reduce $\therefore$ fruit production.

\subsection{Nimroz}

The province of Nimroz is located in southern Afghanistan. It has a population of 136,300 and is surrounded in the north by Farah, in the south by Pakistan, in the west by Iran and in the east by Helmand. The total area of Nimroz is 41,356 square kilometers. It has a total of 5 districts including the capital city of Zaranj. The districts and their population are depicted in table 3 .

Table 3: Districts of Nimroz and their estimated population

\begin{tabular}{ll}
\hline Districts & Population \\
\hline Asli Chakhansur & 26100 \\
Kang & 21800 \\
Charburjak & 32800 \\
Khashrud & 17000 \\
Zarang & 38600 \\
\hline Total & 136300 \\
\hline Source: Estimated population of Afghanistan (1996-1997), Central statistics office, Islamic State of Afghanistan
\end{tabular}

Nimroz has hot summers and cool winters. It also has 120 days of strong wind starting in the month of June. People grow field crops such as wheat, maize, mung beans, barley and some fruits such as melon, watermelon and grapes. Local people raise cows, sheep and goats too.

According to the local authorities in Nimroz and the Manager of Voluntary Association for the Rehabilitation of Afghanistan (VARA), Nimroz province is also severely hit by the drought. $80 \%$ of agriculture in Khashrud and Charburjak and $95 \%$ of livestock in Chakhansur and Kang areas are severely affected. Out of the total population of Nimroz province 109,040 persons, $80 \%$ are severely affected.

Nimroz is one of the poorest and most underdeveloped province in Afghansistan. Previous regimes paid very little attention to the plight of the people in this province. Among all other misery in this province like limited educational and health facilities, poor infrastructure, and limited socio-economic activities, the 
quality of drinking water is extremely poor. They have been drinking salty water for years.

The drought has further worsened the living conditions of Nimroz population. The districts of Khashrud and Charburjak where farmers grow field crops such as wheat, and barley use water from the rivers for irrigation. The Khashrud river which flows through Nimroz is completely dry in some parts and in other parts it has very little water which is not enough for irrigation.

In Chakhansur area, according to Taliban representatives, 250 Kharwar of wheat $(112,500$ Kilos) were cultivated, but due to the lack of water, the entire crop has been lost. It is important to add that $80 \%$ of field crops especially wheat were $\overrightarrow{6}$ estimated to be damaged by the drought.

Sistan lake which has an area of 1200 square $\mathrm{Km}$ is completely dry and has no water. This lake used to have a lot of fish and provided enough water for agriculture. The Helmand river which passes through Nimroz and goes to Iran is also completely dry in Nimroz.

People in Chakhansur and Kang area of Nimroz raise livestock like cows, sheep and goats. These two areas are also very badly affected by drought. According to the interview with Taliban representatives, 300 families of local livestock owners were severely affected, having lost $90 \%$ of their livestock. These people are in desperate need of food, feed and water.

Nomads also live in Nimroz, their exact number isn't known, however, according to our inquires, it is estimated that 20,000 nomads are severely affected by drought, and require emergency assistance of food and feed.

On our way to Zaranj, the capital city of Nimroz, we talked with a Kochi family in the village of Rakin. The family told us that kochis have lost almost $90 \%$ of livestock especially sheep and goats due to the lack of fodder and water. The family further added that many of the kochis who had lost their animals have fled to Badghis and Iran. Zaranj, the capital city, has a $2 \mathrm{~km}$ border with Iran. People from Zaranj easily enter Iran and do business there. They take some goods from Nimroz and sell them there and bring back some needed items from Iran and sell them in Nimroz.

According to VARA, $80 \%$ of the Nimroz population is affected by drought, and need food and water to survive. Moreover, 45,000 livestock owners need feed for their remaining livestock.

Malaria and Chlora and other contagious disease are common in Nimroz especially when the weather gets hot and there is no clean water. It should be noted that there are no health clinics in Nimroz. Dusts, dirt roads and uncleaned environment further makes the life of people miserable. 


\section{GOVERNMENT/NGO RESPONSE}

Local authorities have evacuated a portion of nomads (kochis) in Kandahar and Helmand provinces, from the areas were there were no grazing land and water left and animals were faced with starvation. The kochis were transported to Badghis, Ghazni and Herat provinces.

Taliban Authorities told us in our interviews with them in Kandahar, Helmand and Nimroz, that they don't have funds and the means to help the drought affectees. The Taliban authorities are looking to the international community for assistance.

NGOs such as VARA, ADA and MCI working in the southern region mentioned $\therefore$ to us that they don't have any special program in response to the drought. They are performing some surveys to find out the real facts about the drought and its affects on agriculture, livestock and people of the region as a whole.

The UN agencies and European Union are also conducting surveys and are gathering information about the drought affected areas and it's diverse affect on the people of the southern region and Afghanistan as a whole.

WFP has taken some practical measures against drought and has distributed 3000 cards in Kandahar province that will give $200 \mathrm{~kg}$ of wheat to each card holder for 2 months. Totally 40,000 tons of wheat will be distributed in the coming 12 months. The drought affected population (nomads, local livestock owners and farmers) who were consulted mentioned that they have received no financial assistance from any organization. They were in desperate need of food, feed and water.

It has to be mentioned that the drought in southern Afghanistan is very serious and it is going to get worse if the lack of rain and shortage of water continues in the future. If the drought related problems are not foreseen and averted, undesirable consequences and other social and economical problems will spread in the region and in the whole country. 


\section{APPENDIX \\ QUESTIONNAIRE USED DURING CONSULTATION}

DROUGHT ASSESSMENT IN SOUTHERN AFGHANISTAN

(KANDAHAR, HELMAND AND NIMROZ)

1. Since when has the drought started?

2. What areas of Agriculture (Cereals, Fruits, Vegetables, Industrial crops) and - livestock are affected by drought?

3. Which of the above areas are affected the most?

4. What was total production of cereals especially Irrigated wheat and rainfed wheat before the drought and how much will be estimated after the drought?

5. What was yield /Jirib for the above field crops especially for Irrigated wheat and rain-fed wheat before the drought and how much can you estimate after the drought?

6. Based on your opinion, what $\%$ can you estimate to be the loss of total crop production due to the current drought?

7. What are the sources of your Irrigation?

Karezes

Canals

Wells

8. How are conditions of current Irrigation structures?

Good shape

Demolished

Need repairment

9. Is there enough water for growing your crops and raising livestock?

Yes No

If no, Can you tell by how much is the amount of water decreased in?

Karezes

Canals

Wells

10. What Agricultural inputs (Irrigation water, new or repairment of Irrigation structures, fertilizers, improved seed varieties, Agro-chemicals, credit and agricultural machines) do you need in order to combat the hardship and problems caused by the drought? 
11. Do you raise livestock? Yes:

No:
If yes, What type?

12. Is your livestock affected by drought?

Due to shortage of water

Feed

Pasture and Grazing land

13. What $\%$ of livestock do you think is lost by drought?

14. Are there any nomads (kochis) Population in area?

Yes: No:

6 If yes, what $\%$ of the population do they comprise?

15. Are their livestock affected by the drought?

If yes, by how much?

16. How often has it rained this year?

17. Can you make any comparison of the rain between this year and last year?

18. Do you grow the same crops every year?

If yes, what are they?

If No, do you rotate crops?

18.1. And in your opinion which crops need less water and are more drought resistant?

19. Is there any shortage of major food Items such as wheat, Rice, Meat, Beans, Eggs? If yes, how much? Have their prices risen and what is the comparison of prices to the years before the drought?

20. Do you have any other source of income beside Agriculture and livestock?

Yes.

No.

If yes, what are they and can you cope with the economic problems caused by drought?

21. What do you think is needed to remedy your Agricultural and livestock problems?

22. What localities or district areas are affected by the drought?

In kandahar

In Helmand

In Nimroz 
23. What $\%$ of the population is affected by the drought?

In Kandahar

In Helmand

In Nemtoz

24. What do you need immediately to combat the misery caused by the drought?

25. Are there any Extension activities available to you concerning?
A: Agriculture
B: Livestock

26. What assistance is provided to you in time of drought by?
A: Local Authorities
B: NGOs
C: International Organizations

27. What other problems and difficulties are created by drought beside areas of agriculture and livestock? 